\title{
Utilization of Glycine by Microorganisms along the Altitude Changbai Mountain, China: An Uptake Test Using ${ }^{13} \mathrm{C}_{,}^{15} \mathrm{~N}$ Labeling and ${ }^{13}$ C-PLFA Analysis
}

\author{
Yan Xue ${ }^{1,2}$, Zhijie Wu ${ }^{1, *}$, Lili Zhang ${ }^{1}$, Wei Bai ${ }^{3,4}$, Dongpo Li ${ }^{1} \mathbb{D}$, Lijie Yang ${ }^{5}$, Ping Gong ${ }^{1}$, Zhanbo Wei ${ }^{1}$, \\ Yuchao Song ${ }^{1}$, Lei Cui ${ }^{1,2} \mathbb{D}$, Kaikuo $\mathrm{Wu}^{1}$ and Furong Xiao ${ }^{1,2}$ \\ 1 Institute of Applied Ecology, Chinese Academy of Sciences, Shenyang 110016, China; \\ xueyanchina@163.com (Y.X.); llzhang@iae.ac.cn (L.Z.); lidp@iae.ac.cn (D.L.); \\ gongping5841751@163.com (P.G.); huanke217@163.com (Z.W.); songyuchao@iae.ac.cn (Y.S.); \\ cuilei0121@163.com (L.C.); kkwu@iae.ac.cn (K.W.); xiaofurong0911@163.com (F.X.) \\ 2 University of Chinese Academy of Sciences, Beijing 100049, China \\ 3 Liaoning Key Laboratory of Conservation Tillage in Dry Land, Tillage and Cultivation Research Institute, \\ Liaoning Academy of Agricultural Science, Shenyang 110016, China; libai200008@126.com \\ 4 National Agricultural Experimental Station for Agricultural Environment, Fuxin 123102, China \\ 5 Shenyang Research Institute of Chemical Industry, Shenyang 110021, China; ylj402@163.com \\ * Correspondence: wuzj@iae.ac.cn
}

check for updates

Citation: Xue, Y.; Wu, Z.; Zhang, L.; Bai, W.; Li, D.; Yang, L.; Gong, P.; Wei, Z.; Song, Y.; Cui, L.; et al. Utilization of Glycine by Microorganisms along the Altitude Changbai Mountain, China: An Uptake Test Using ${ }^{13} \mathrm{C},{ }_{1}^{15} \mathrm{~N}$ Labeling and ${ }^{13} \mathrm{C}$-PLFA Analysis. Forests 2022, 13, 307. https:// doi.org/10.3390/f13020307

Academic Editor: Marcin Pietrzykowski

Received: 7 January 2022

Accepted: 11 February 2022

Published: 14 February 2022

Publisher's Note: MDPI stays neutral with regard to jurisdictional claims in published maps and institutional affiliations.

Copyright: (C) 2022 by the authors. Licensee MDPI, Basel, Switzerland. This article is an open access article distributed under the terms and conditions of the Creative Commons Attribution (CC BY) license (https:// creativecommons.org/licenses/by/ $4.0 /)$.

\begin{abstract}
External organic nitrogen $(\mathrm{N})$ inputs can contrastingly affect the transformation and availability of $\mathrm{N}$ in forest soils, which is an important potential $\mathrm{N}$ resource and is possibly vulnerable to soil properties. Little is known about the transformation and availability of external small molecule organic $\mathrm{N}$ in forest soils and the underlying microbial mechanisms. Soil samples from Changbai Mountain at different altitudes (from $750 \mathrm{~m}$ to $2200 \mathrm{~m}$ ) that ranged widely in soil properties were incubated with ${ }^{13} \mathrm{C},{ }^{15} \mathrm{~N}$-labeled glycine. The fate of ${ }^{15} \mathrm{~N}$-glycine and the incorporation of ${ }^{13} \mathrm{C}$ into different phospholipid fatty acids (PLFAs) were measured at the same time. The addition of glycine promoted gross $\mathrm{N}$ mineralization and microbial $\mathrm{N}$ immobilization significantly. Mineralization of glycine $\mathrm{N}$ accounted for $6.2-22.5 \%$ of the added glycine and can be explicable in the light of a readily mineralizable substrate by soil microorganisms. Assimilation of glycine $\mathrm{N}$ into microbial biomass by the mineralization-immobilization-turnover (MIT) route accounted for $24.7-52.1 \%$ of the added label and was most mightily affected by the soil $\mathrm{C} / \mathrm{N}$ ratio. We also found that the direct utilization of glycine is important to fulfill microorganism growth under the lack of available carbon (C) at upper elevations. The labeled glycine was rapidly incorporated into the PLFAs and was primarily assimilated by bacteria, indicating that different groups of the microbial community were answerable to external organic N. G+ bacteria were the main competitors for the exogenous glycine. Increased intact incorporation of glycine into microbial biomass and the concentration of PLFAs in general, particularly in G+ bacteria, suggest a diversified arrangement to response changes in substrate availability.
\end{abstract}

Keywords: glycine; organic N uptake; soil microorganisms; PLFA; Changbai Mountain

\section{Introduction}

$\mathrm{N}$, especially inorganic $\mathrm{N}$, is an essential, but often the most limiting, element for microbial growth and plant productivity in global forest ecosystems [1]. As an important $\mathrm{N}$ input pathway, elevated anthropogenic organic $\mathrm{N}$ from a wide range of sources relieves $\mathrm{N}$ limitation for microorganisms and plants [2]. In addition, detailed studies have shown that as a main compound of low-molecular-weight organic substances, amino acids in northern forests play an important role in $\mathrm{N}$ cycling especially at high elevations and high latitudes, where the availability of mineral $\mathrm{N}$ is not sufficient to plants [3-5]. Many of the 
detailed studies about amino acid behavior in soil, including providing available $\mathrm{N}$ sources for plants and microorganisms, have come from agricultural or grassland soils [6-8], with a comparative scarcity of studies from boreal forest soils [9], Arctic soils [10], and alpine zones [11]. Thus, a systematic understanding of external amino acid transformation in forest soils is essential to forecast its effects on the soil $\mathrm{N}$ cycle in forest system. Glycine is often used as an important organic $\mathrm{N}$ source in field research because of its abundance in many soils, and its metabolism has been well characterized and can be utilized rapidly by microorganisms [12-14].

Microorganisms have developed different mechanisms that dominate their longevity in soil solution for the uptake and assimilation of exogenous amino acid N, although amino acid $\mathrm{N}$ can be used by plants, abiotically mineralized, leached, and adsorbed to the solid phase [15-17]. The two pathways are generally known as the mineralizationimmobilization-turnover (MIT) route (Organic $\mathrm{N}$ is first mineralized to ammonium and then ammonium is taken up by microorganisms in soil) [18] and direct route (organic $\mathrm{N}$ can be directly and intactly taken up by soil microorganisms) [12,19]. Hence, $\mathrm{N}$ mineralization and $\mathrm{N}$ immobilization of the soil microorganisms are the major pathways related to the retaining $\mathrm{N}$ in soil [20-22]. Because the enzyme reactions involved are complex, the $\mathrm{N}$ mineralization rates and $\mathrm{N}$ immobilization in microbial biomass are variable, depending on substrate quantity (soil $\mathrm{N}$ concentration), quality ( $\mathrm{C} / \mathrm{N}$ ratios) and soil physicochemical properties [23,24]. The soil $\mathrm{C} / \mathrm{N}$ ratio is often described as a key factor to predict $\mathrm{N}$ immobilization with organic $\mathrm{N}$ added in models [25]. However, the relationship between $\mathrm{N}$ immobilization and the soil $\mathrm{C} / \mathrm{N}$ ratio is uncertain in forest soils. For instance, in a ${ }^{15} \mathrm{~N}$ tracing study, the highest $\mathrm{NH}_{4}{ }^{+}$immobilization was found in the treatment with a low soil C/N ratio [26-29], while there was no correlation between $\mathrm{NH}_{4}{ }^{+}$immobilization and the soil C/N ratio. In many cases, the increase in soil C/N (15 to 30) did not promote microbial N immobilization [30-32], which is inconsistent with the assertion that microbial $\mathrm{N}$ immobilization was accelerated in the high $\mathrm{C}$ availability by stimulating heterotrophic microorganisms [33]. The transformation of amino acids to the soil $\mathrm{N}$ by microbial uptake was quite different in the available $\mathrm{N}$ limited, low-temperature forest soils, such as in alpine tundra, Arctic, and boreal forest ecosystems, while the details of transformations are strongly limited compared to agricultural soils and grassland soils [7,34,35]. Only a few studies have focused on the contribution of the MIT and direct routes to the N nutrition of soil microorganisms, and little is known about the factors involved in the importance of the two pathways in soil [8].

${ }^{13} \mathrm{C}$-phospholipid fatty acid (PLFA) is an accurate method for evaluating which microbial community actively assimilates the exogenous amino acid in forest soils [36,37]. Recent studies of substrate incorporation into PLFA biomarkers have shown that bacteria prefer to utilize amino acids rapidly, while fungi are slower than bacteria in soluble organic soil $\mathrm{N}$ turnover [38]. Glycine is mostly acquired by bacteria and not fungi in tundra soil [39]. Coupling PLFA analysis with ${ }^{13} \mathrm{C}$ labeling has shown that G- bacteria $(16: 1 \omega 7 \mathrm{c}$ and $18: 1 \omega 7 \mathrm{c})$ and universal (16:0), were more abundant and active in amino acid utilization than G+ bacteria [40-42]. However, some previous studies indicated that the use of ${ }^{13} \mathrm{C}$-enriched microbes to trace ${ }^{13} \mathrm{C}$ in PLFAs has shown that fungi [43] or G+ bacteria [44] are the most active consumers of freshly added glycine substrates. Consequently, members of the microbial community are differentially involved in the assimilation of amino acids, and the activity of individual microbial groups appears to depend on environmental conditions such as soil type and availability of C and N [45]. Thus, general principles of amino acid utilization by individual groups of bacteria and fungi remain open.

The forest ecosystems in Changbai Mountain, Northeast China, are very important, range in altitude from $750 \mathrm{~m}$ to $2700 \mathrm{~m}$ and include needle mixed forests, Korean pinespruce forest, dark coniferous forest, birch forests and alpine tundra, which are temperate and cold forests and sensitive to global climate change. It should be noted that variation in altitudes has been shown to lead to changes not only in temperature but also in factors such as soil properties [46]. It has been found that exogenous organic $\mathrm{N}$ generally promoted 
gross $\mathrm{N}$ mineralization in the main temperate forest of Changbai Mountain [47]. However, we lack a clear understanding of how amino acid addition affects gross $\mathrm{N}$ transformation under different soil properties. Recent studies showed that in alpine tundra soil, as one of the popular issues for extractable organic $\mathrm{N}$, soil microbes were more efficient in the uptake of intact amino acids than inorganic $\mathrm{N}$, especially in bacteria [39]. Hence, it is important to conduct research on the utilization of exogenous amino acids along Changbai Mountain at different altitudes.

In this study, we carried out a dual-labeled glycine study with soils from forests at various altitudes in Changbai Mountain, Northeast China, which have a wide range of soil properties. The selected substrate glycine represented organic $\mathrm{N}$ sources present in soils. The objects of our study were to (1) investigate amino acid transformation and its effect on soil gross $\mathrm{N}$ transformation rates and microbial $\mathrm{N}$ immobilization and (2) to assess the microbial community to utilize exogenous amino acids. We first hypothesized that the addition of amino acids will increase microbial $\mathrm{N}$ immobilization, which in turn will promote $\mathrm{N}$ retention. Second, we hypothesized that microbes can acquire amino acid $\mathrm{N}$ by way of the MIT route and a direct route even under the limitation of available C and N. Bacteria are responsible for the utilization of freshly added amino acid substrates.

\section{Materials and Methods}

\subsection{Study Site and Soil Collection}

Changbai Mountain $\left(41^{\circ} 23^{\prime}-42^{\circ} 36^{\prime} \mathrm{N} ; 126^{\circ} 55^{\prime}-129^{\circ} 00^{\prime} \mathrm{E}\right)$ is located in Jilin Province, Northeast China, which extends along the border of China and North Korea. Along the increasing altitudinal gradient from 720 to $2691 \mathrm{~m}$, the vegetation types and climate characteristics have been well documented in previous studies $[48,49]$. The five sites were selected along an altitude gradient from $750 \mathrm{~m}$ to $2200 \mathrm{~m}$, with samples collected at $750 \mathrm{~m}\left(42^{\circ} 24^{\prime} \mathrm{N}, 128^{\circ} 06^{\prime} \mathrm{E}\right), 1320 \mathrm{~m}\left(42^{\circ} 09^{\prime} \mathrm{N}, 128^{\circ} 07^{\prime} \mathrm{E}\right), 1570\left(42^{\circ} 05^{\prime} \mathrm{N}, 128^{\circ} 04^{\prime} \mathrm{E}\right), 1810$ $\left(42^{\circ} 03^{\prime} \mathrm{N}, 128^{\circ} 04^{\prime} \mathrm{E}\right)$, and $2200 \mathrm{~m}\left(42^{\circ} 02^{\prime} \mathrm{N}, 128^{\circ} 04^{\prime} \mathrm{E}\right)$. Details of the soil characteristics and vegetations are provided in Table 1 and Figure S2.

Table 1. The chemical properties of the studied sites.

\begin{tabular}{|c|c|c|c|c|c|}
\hline & $750 \mathrm{~m}$ & $1320 \mathrm{~m}$ & $1570 \mathrm{~m}$ & $1810 \mathrm{~m}$ & $2200 \mathrm{~m}$ \\
\hline $\begin{array}{l}\text { Soil moisture } \\
\text { content }\end{array}$ & $0.32 \pm 0.02^{b}$ & $0.33 \pm 0.04^{b}$ & $0.34 \pm 0.01^{\mathrm{a}, \mathrm{b}}$ & $0.41 \pm 0.2^{\mathrm{a}, \mathrm{b}}$ & $0.47 \pm 0.04^{\mathrm{a}}$ \\
\hline $\mathrm{pH}$ & $4.68 \pm 0.18^{b}$ & $4.83 \pm 0.17^{b}$ & $4.27 \pm 0.13^{c}$ & $4.21 \pm 0.12^{c}$ & $5.37 \pm 0.15^{\mathrm{a}}$ \\
\hline Total C (\%) & $5.38 \pm 1^{\mathrm{b}}$ & $3.04 \pm 0.13^{b}$ & $4.73 \pm 0.34^{b}$ & $10.68 \pm 1.94^{\mathrm{a}}$ & $6.47 \pm 1.45^{b}$ \\
\hline Total N (\%) & $0.46 \pm 0.07^{\mathrm{a}}$ & $0.16 \pm 0.01^{b}$ & $0.28 \pm 0.01^{b}$ & $0.51 \pm 0.11^{\mathrm{a}}$ & $0.39 \pm 0.06^{\mathrm{a}}$ \\
\hline Soil C/N & $11.63 \pm 0.47^{c}$ & $19.59 \pm 0.82^{\mathrm{a}, \mathrm{b}}$ & $17.21 \pm 0.89^{b}$ & $20.77 \pm 2.24^{\mathrm{a}}$ & $16.37 \pm 1.12^{b}$ \\
\hline $\begin{array}{c}\mathrm{NH}_{4}^{+}-\mathrm{N} \\
\left(\mathrm{mg} \mathrm{kg}^{-1}\right)\end{array}$ & $18.8 \pm 6.48^{a}$ & $9.24 \pm 1.53^{b}$ & $27.44 \pm 4.22^{\mathrm{a}}$ & $32.41 \pm 8.07^{\mathrm{a}}$ & $23.67 \pm 5.48^{\mathrm{a}}$ \\
\hline $\begin{array}{c}\mathrm{NO}_{3}-\mathrm{N} \\
\left(\mathrm{mg} \mathrm{kg}^{-1}\right)\end{array}$ & $49.49 \pm 3.02^{\mathrm{a}, \mathrm{b}}$ & $42.79 \pm 6.31^{b}$ & $58.7 \pm 7.55^{\mathrm{a}}$ & $5.26 \pm 2.05^{c}$ & $5.64 \pm 2^{c}$ \\
\hline $\begin{array}{c}\mathrm{MBC} \\
\left(\mathrm{mg} \mathrm{kg}^{-1}\right)\end{array}$ & $1208.95 \pm 131.91^{\mathrm{a}}$ & $803.56 \pm 146.96^{b}$ & $597.03 \pm 58.55^{b}$ & $881.25 \pm 187.64^{b}$ & $1083.45 \pm 166.75^{a, b}$ \\
\hline $\begin{array}{c}\text { MBN } \\
\left(\mathrm{mg} \mathrm{kg}^{-1}\right)\end{array}$ & $203.26 \pm 41^{a}$ & $199.18 \pm 25.41^{a}$ & $76.57 \pm 21.36^{b}$ & $181.05 \pm 65.24^{\mathrm{a}}$ & $208.57 \pm 23.8^{a}$ \\
\hline
\end{tabular}
for each elevation at $p<0.05$.

From each site, we selected six areas under the same vegetation. Soil samples were randomly collected from 10 points in an area of $20 \mathrm{~m} \times 20 \mathrm{~m}$ and the samples were pooled together as a composite sample. The visible roots and residues were removed before homogenization of the soil fraction of each sample. The fresh soil samples were sieved $(2 \mathrm{~mm})$ and stored at $4{ }^{\circ} \mathrm{C}$ to determine its chemical properties, and the labeled glycine was added for analysis. 


\subsection{Soil Chemical Analysis}

The soil $\mathrm{pH}$ was determined with a soil/water ratio $(1 / 2.5)$. The soil nitrate nitrogen $\left(\mathrm{NO}_{3}{ }^{-} \mathrm{N}\right)$ and ammonium nitrogen $\left(\mathrm{NH}_{4}{ }^{+}-\mathrm{N}\right)$ were extracted with $2 \mathrm{M} \mathrm{KCl}$ (soil: extract/1:5) and determined by a continuous flow analyzer ( $\mathrm{AA}_{3}$, Bran + Luebbe, Germany). The soil total C (TC) and total N (TN) contents were determined by dry combustion of the samples (100-mesh) using an Elemental Analyzer (Vario EL III, Hanau, Germany). The TC content was equal to the soil organic $\mathrm{C}$ content because of these soils free of carbonates [50]. Soil microbial biomass $\mathrm{C}(\mathrm{MBC})$ and $\mathrm{N}(\mathrm{MBN})$ were also measured by the $\mathrm{CHCl}_{3}$ fumigation-extraction method [51]. From one sample fraction, soil was immediately extracted with $0.5 \mathrm{M} \mathrm{K}_{2} \mathrm{SO}_{4}$, and the other fraction was extracted after fumigated with $\mathrm{CHCl}_{3}$ for $24 \mathrm{~h}$. The extraction was measured by a Vario TOC Analyzer (Elementar, Langenselbold, Germany). MBC and MBN were calculated as the difference in extractable $C$ and $N$ between the fumigated and unfumigated soils divided by the fraction of mineralizable biomass $\mathrm{C}$ $(\mathrm{kC}) \frac{1}{4} 0.45$ and the fraction of mineralizable biomass $\mathrm{N}(\mathrm{kN}) \frac{1}{4} 0.54$ [49].

\subsection{Gross N Mineralization}

The gross $\mathrm{N}$ mineralization rate $(\mathrm{m})$ was determined by a mirror image pool dilution approach [19]. From one sample fraction, soil was treated with $\left({ }^{15} \mathrm{NH}_{4}\right)_{2} \mathrm{SO}_{4}(60$ atom\%) and then extracted immediately with $0.5 \mathrm{M} \mathrm{K}_{2} \mathrm{SO}_{4}$. The other fraction was extracted after treated with $\left({ }^{15} \mathrm{NH}_{4}\right)_{2} \mathrm{SO}_{4}\left(60\right.$ atom\%) for $6 \mathrm{~h}$. For two parts of sample fractions, $\mathrm{NH}_{4}{ }^{+}-\mathrm{N}$ was determined above. The atom $\%{ }^{15} \mathrm{~N}$ of the $\mathrm{NH}_{4}{ }^{+}$pool was determined according to Sebilo et al. [52]. The set-up of experiment in the atom $\%{ }^{15} \mathrm{~N}$ of the $\mathrm{NH}_{4}{ }^{+}-\mathrm{N}$ was shown in Figure S3 In brief, a circle glass fiber filter (APFE, $25 \mathrm{~mm}$, Millipore) treated with $2.5 \mathrm{M}$ $\mathrm{KHSO}_{4}$ was enclosed with a hydrophobic and breathable filter to form a filter package for technique of the $\mathrm{NH}_{4}{ }^{+}$diffusion. Combined with $0.5 \mathrm{~g} \mathrm{MgO}$, the extracting solution with the filter package was shaken slowly for 7 days at room temperature, and then the package was removed and dried in a freezing dryer for $12 \mathrm{~h}$. The glass fiber was taken out to analyze atom $\%{ }^{15} \mathrm{~N}$ with an isotope ratio mass spectrometer (253 MAT, Thermo Finnigan, Karlsruhe, Germany). Gross N mineralization was determined according to Barraclough (1995) for ${ }^{15} \mathrm{NH}_{4}{ }^{+}$isotope dilution techniques by Equation (1) below.

$$
\mathrm{m}=\theta \cdot \log _{\left(1+\theta / A_{0}\right)}^{A_{*}^{*} / A_{t}^{*}}
$$

where the rate at which the pool size changes $(\theta)$ is given by $\left(A_{t}-A_{0}\right) / t ; A_{0}$ represents the $\mathrm{NH}_{4}{ }^{+}-\mathrm{N}$ at time $0 ; \mathrm{A}_{\mathrm{t}}$ represents the $\mathrm{NH}_{4}{ }^{+}-\mathrm{N}$ at time $t$ which was determined on the samples to which ${ }^{15} \mathrm{NH}_{4}{ }^{+}$was added and extracted after $6 \mathrm{~h} ; A_{0}{ }^{*}$ represents the atom\% $\%{ }^{15} \mathrm{~N}$ excess of the $\mathrm{NH}_{4}{ }^{+}$pool at time $0 ; A_{t}{ }^{*}$ represents the atom $\%{ }^{15} \mathrm{~N}$ excess of the $\mathrm{NH}_{4}{ }^{+}$pool at time $t$ which was determined on the samples to which ${ }^{15} \mathrm{NH}_{4}{ }^{+}$was added and extracted after $6 \mathrm{~h}$.

\subsection{Different Form of ${ }^{15} \mathrm{~N}$ Glycine Uptake}

In our research, we applied glycine as an organic $\mathrm{N}$ source to obtain results that would be relevant to previous research. ${ }^{13} \mathrm{C},{ }^{15} \mathrm{~N}$-glycine ( $5 \mathrm{mg} \mathrm{N} \mathrm{kg}^{-1}$ dry soil) was applied to the soil for $6 \mathrm{~h}$. The ${ }^{13} \mathrm{C}$ and ${ }^{15} \mathrm{~N}$ atom $\%$ was $98 \%$ and $99 \%$ at the $\mathrm{C}_{2}$ position.

The ${ }^{15} \mathrm{~N}$ atom $\%$ of the $\mathrm{NH}_{4}{ }^{+}$was according to Sebilo et al. [52], which was described and analyzed as described for determination of the gross $\mathrm{N}$ mineralization above. For measurement of ${ }^{15} \mathrm{NO}_{3}{ }^{-}$, solutions of the subsamples were combined with $0.3 \mathrm{~g}$ Devarda alloy reagent (Merck, Germany) to transform ${ }^{15} \mathrm{NO}_{3}{ }^{-}$to ${ }^{15} \mathrm{NH}_{4}{ }^{+}$, and samples were analyzed with a diffusion package technique as described above.

The direct ${ }^{13} \mathrm{C},{ }^{15} \mathrm{~N}$-glycine utilization by microorganisms was measured by the method of Geisseler and Horwath [53]. Fumigated subsamples with $\mathrm{CHCl}_{3}$ and sodium dodecyl sulfate for $24 \mathrm{~h}$, and unfumigated subsamples were extracted with $0.5 \mathrm{M} \mathrm{K}_{2} \mathrm{SO}_{4}$, and the extracts were analyzed for ${ }^{13} \mathrm{C}_{1}^{15} \mathrm{~N}$-glycine. Nonvolatile dual-labeled glycine was derived by methyl-chloroformate before GC analysis according to Geisseler and 
Smart et al. [53,54]. The separation and measurement of methyl chloroformate derivatives were performed according to Smart et al. [54]. The ${ }^{13} \mathrm{C},{ }^{15} \mathrm{~N}$-glycine derivatives were determined by a Thermo Scientific TRACE GC with a Thermo Scientific ITQ 1100 ion-trap mass spectrometer (Finnigan trace, Thermo Electron Co. Ltd., Pittsburgh, PA, USA).

For measurement of ${ }^{15} \mathrm{~N}$ atom $\%$ in the microbial biomass by both MIT route and direct route, fumigated with $\mathrm{CHCl}_{3}$ for $24 \mathrm{~h}$ and unfumigated subsamples were extracted with $0.5 \mathrm{M} \mathrm{K}_{2} \mathrm{SO}_{4}$, and then $4 \mathrm{~mL}$ of solution was digested to transform microbial biomass $\mathrm{N}$ to $\mathrm{NO}_{3}{ }^{-}$by Cabrera et al. [55]. Combined with $0.3 \mathrm{~g}$ Devarda alloy reagent, ${ }^{15} \mathrm{NO}_{3}{ }^{-}$was transformed to ${ }^{15} \mathrm{NH}_{4}{ }^{+}$, and was subjected to the diffusion package method according to Sebilo et al. [52]. To get the ${ }^{15} \mathrm{~N}$ atom $\%$ assimilated to soil microbial biomass by MIT route $\left({ }^{15} \mathrm{~N}-\mathrm{MBN}\right)$, we deducted the direct ${ }^{13} \mathrm{C},{ }^{15} \mathrm{~N}$-glycine utilization by microorganisms from the ${ }^{15} \mathrm{~N}$ atom $\%$ in the microbial biomass nitrogen.

\section{5. ${ }^{13}$ C-PLFA Analysis}

A modified Bligh and Dyer method described in Ma et al. [8] was applied for the extraction of PLFAs, with minor modifications. The freeze-dried soil treated with Bligh Dyer solvent (methanol/chloroform/potassium dihydrogen phosphate and dipotassium phosphate-buffered $\mathrm{H}_{2} \mathrm{O}$ at $\mathrm{pH}$ 7.2 at 10:5:4 v:v:v) in a 3:1 ratio, and the samples were vortexed prior to centrifugation. The organic phase was saved and extracted (three times) with chloroform in a separating funnel. All organic extracts were combined and exposed to $\mathrm{N}_{2}$ atmosphere for the evaporation of solvent. Silica acid columns with the solvent system (chloroform, acetone, methanol in 1:2:1 v:v:v) were used to isolate the phospholipid fraction from the total lipid extract. After saponification (methanol, methylbenzene, $0.2 \mathrm{M} \mathrm{KOH}$ ) and acidification (1 M acetic acid), the liberated PLFAs were extracted with hexane. Before derivatization, methyl nonadecanoate fatty acid (19:0) was added as an internal standard. PLFAs were determined by a gas chromatograph (GC 7890A; Agilent, CA, USA) with the MIDI Sherlock microbial identification system 6.2B (MIDI, Newark, DE, USA). The $\delta^{13} \mathrm{C}$ marker of PLFAs was determined by gas chromatography combustion isotope ratio mass spectrometry (GC-C-IRMS, Thermo-Fisher Scientific, MA, USA) with GC combustion as described previously [56].

The mid-chain and terminally branched fatty acids (i15:0, a15:0, i16:0, 10Me16:0, i17:0, a17:0, 10Me17:0, and 10Me18:0) were considered to represent G+ bacteria, and monounsaturated $(18: 1 \omega 9 \mathrm{c}, 16: 1 \omega 9$ and 18:1 $1 \omega 7)$ and cyclopropyl saturated (cy-17:0 and cy-19:0) fatty acids were considered to represent $G-$ bacteria. The fatty acids 18:2 $\omega 6$ and 9 were considered to represent fungal origin $[57,58]$. The amount of $8^{13} \mathrm{C}$ in individual PLFAs was calculated according to Andresen et al. [42].

\subsection{Statistical Analysis}

Data in the graphs were presented as the mean \pm standard error. To assess differences among treatments, one-way ANOVA was conducted with Tukey's multiple comparisons $(p<0.05)$. ANOVAs and linear regression were performed using SPSS 22.0. To test the effect of soil physiochemical parameters on the transformation of glycine and $\delta^{13} \mathrm{C}$ microbial communities in the soil, ${ }^{13} \mathrm{C}$-PLFA data and glycine date were analyzed by redundancy analysis (RDA) using CANOCO 5.0 (Microcomputer power, Ithaca, NY, USA). Figures were performed using Origin 9.0.0 (OriginLab, Northampton, MA, USA).

\section{Results}

\subsection{Glycine-Addition Effects: Gross N Mineralization}

For each elevation, we did not detect that glycine addition significantly changed the net $\mathrm{N}$ mineralization rate (Figure S1), while glycine addition significantly increased both gross $\mathrm{N}$ mineralization and MBN compared to their respective controls (Figures 1 and 2). Specific gross $\mathrm{N}$ mineralization was applied to indicate the activity of gross $\mathrm{N}$ mineralization that only considering microbial biomass $\mathrm{N}$ as a mineralization substrate. Specific gross $\mathrm{N}$ mineralization equates gross $\mathrm{N}$ mineralization/microbial biomass $\mathrm{N}$. Compared 
to the control, specific gross $\mathrm{N}$ mineralization increased in all the treatments $(p \leq 0.05)$ (Table 2). At $1570 \mathrm{~m}, 1810 \mathrm{~m}$ and $2200 \mathrm{~m}$ elevations, gross $\mathrm{N}$ mineralization was negatively correlated with the microbial $\mathrm{C} / \mathrm{N}$ ratio, and at $750 \mathrm{~m}$ and $1320 \mathrm{~m}$, gross $\mathrm{N}$ mineralization was positively correlated with both the microbial $\mathrm{C}$ and microbial $\mathrm{C} / \mathrm{N}$ ratios (Table 3). Moreover, considering each elevation, we did not find any significant correlations of soil physicochemical characteristics with gross $\mathrm{N}$ mineralization and MBN (Table S2).

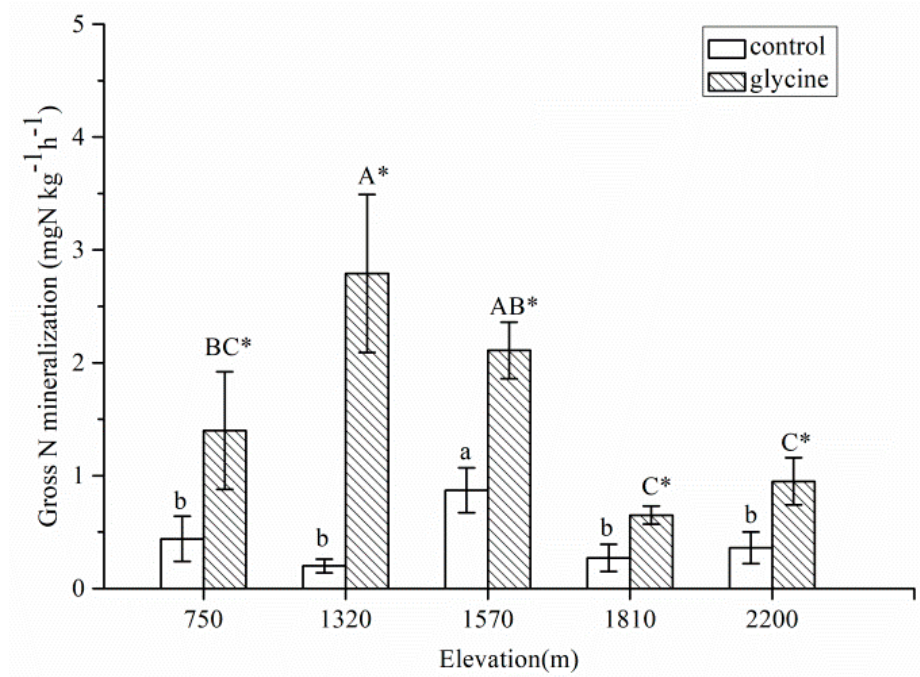

Figure 1. Gross $\mathrm{N}$ mineralization in soils according to elevation gradients. Error bars represent standard deviations of means; $n=6$. Different lowercase letters above the bar indicate significant differences among the controls of each elevation, and different capital letters indicate significant differences among treatments for each elevation $(p<0.05)$. Asterisks indicate significant differences between the control and glycine addition at each elevation (Paired-Samples $t$-test at $p<0.05$ ). Control had no $\mathrm{N}$ addition; glycine had received glycine with $5 \mathrm{mg} \mathrm{N} \mathrm{kg}^{-1}$ soil.

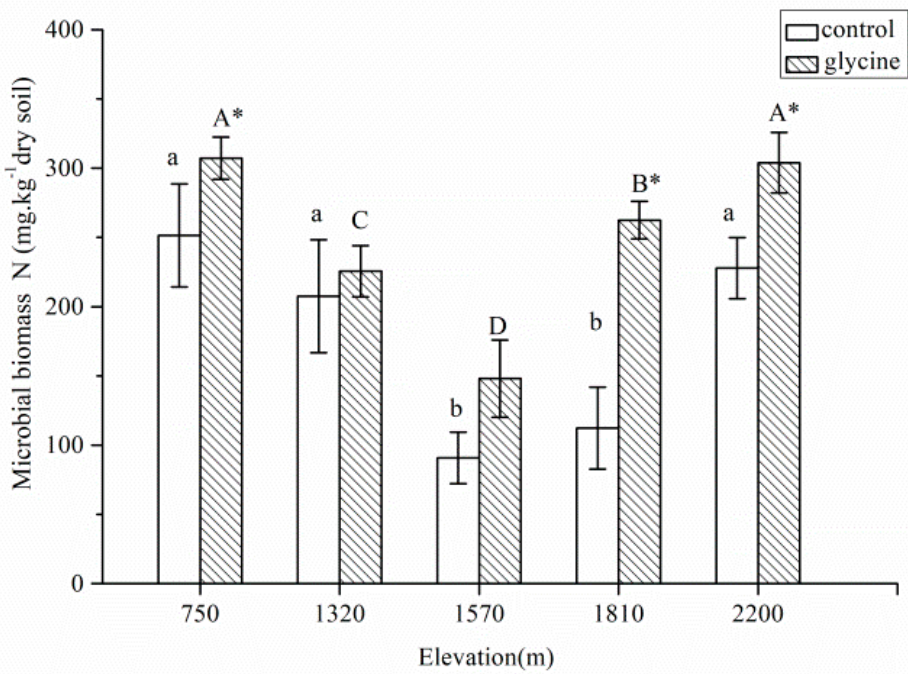

Figure 2. Microbial biomass $\mathrm{N}$ in soils according to elevation gradients. Error bars represent standard deviations of means; $n=6$. Different lowercase letters above the bar indicate significant differences among the controls of each elevation, and different capital letters indicate significant differences among treatments for each elevation $(p<0.05)$. Asterisks indicate significant differences between the control and glycine addition at each elevation (Paired-Samples $t$-test at $p<0.05$ ). Control had no $\mathrm{N}$ addition; glycine had received glycine with $5 \mathrm{mg} \mathrm{N} \mathrm{kg}^{-1}$ soil. 
Table 2. Specific gross $\mathrm{N}$ mineralization according to elevation gradients (means \pm S.D., $n=6$ ).

\begin{tabular}{ccc}
\hline Soil Variable by Elevation & Control & Glycine \\
\hline $750 \mathrm{~m}$ & $0.0018 \pm 0.0013$ & $0.0034 \pm 00008$ \\
$1320 \mathrm{~m}$ & $0.0007 \pm 0.0002$ & $0.0113 \pm 0.0050 *$ \\
$1570 \mathrm{~m}$ & $0.0086 \pm 0.0033$ & $0.212 \pm 0.0111^{*}$ \\
$1810 \mathrm{~m}$ & $0.0023 \pm 0.0017$ & $0.0028 \pm 0.0006$ \\
$2200 \mathrm{~m}$ & $0.0009 \pm 0.0003$ & $0.0031 \pm 0.001$ * \\
\hline
\end{tabular}

Notes: Asterisks indicate significant differences between the control and glycine addition at each elevation (PairedSamples $t$-test at $p<0.05)$. Control had no $\mathrm{N}$ addition; glycine had received glycine with $5 \mathrm{mg} \mathrm{N} \mathrm{kg}^{-1} \mathrm{soil}^{\text {. }}$

Table 3. Pearson correlation coefficients $(n=6)$ among gross $\mathrm{N}$ mineralization, Microbial C, Microbial $\mathrm{N}$, Microbial C: $\mathrm{N}$ ratio for glycine addition treatments at each elevation.

\begin{tabular}{cccc}
\hline Elevation & Microbial C & Microbial N & Microbial C:N Ratio \\
\hline $750 \mathrm{~m}$ & & & 0.598 \\
Gross N mineralization & 0.6 & $-0.79 *$ & $0.827^{*}$ \\
Microbial C & & 0.194 & -0.389 \\
Microbial N & & & $0.710^{*}$ \\
$1320 \mathrm{~m}$ & $0.768^{*}$ & 0.125 & $0.776^{*}$ \\
Gross N mineralization & & 0.341 & -0.327 \\
Microbial C & & & -0.623 \\
Microbial N & $-0.73 *$ & -0.088 & 0.228 \\
1570 m & & 0.561 & -0.668 \\
Gross N mineralization & & & -0.703 \\
Microbial C & & $0.881^{* *}$ \\
MicrobialN & & 0.023 & -0.265 \\
1810 m & -0.699 & 0.221 & $-0.832^{*}$ \\
Gross N mineralization & & & $0.933^{* *}$ \\
Microbial C & & -0.173 & 0.466 \\
Microbial N & -0.697 & $0.752^{*}$ & \\
2200 m & & & \\
Gross N mineralization & & & \\
Microbial C & & & \\
Microbial N & & & \\
\hline
\end{tabular}

${ }^{*} p \leq 0.05 .{ }^{* *} p \leq 0.01$.

\section{2. ${ }^{15} \mathrm{~N}$-Distribution in Soils and Microorganisms}

After ${ }^{13} \mathrm{C},{ }^{15} \mathrm{~N}$-glycine was added to the soil, all of the treatments at each elevation examined were able to rapidly take up ${ }^{15} \mathrm{~N}$ through the MIT route and direct route by microorganisms, although there were differences in the specific uptake rates according to the elevations. The ratio of free ${ }^{15} \mathrm{~N}$-glycine in soils was very low at each elevation treatment. Without regard to glycine left in soil, microbial immobilization of ${ }^{15} \mathrm{~N}$ by MIT route was significantly higher than that of other forms of ${ }^{15} \mathrm{~N}$ at each elevation except for that at $750 \mathrm{~m}$ (Figure 3), and was significantly higher at $1810 \mathrm{~m}$ and $2200 \mathrm{~m}$ than at $750 \mathrm{~m}$, $1320 \mathrm{~m}$ and $1570 \mathrm{~m}$ plot. In comparison, ${ }^{15} \mathrm{~N}_{-} \mathrm{NH}_{4}{ }^{+}$and ${ }^{15} \mathrm{~N}^{-N}{ }_{3}{ }^{-}$were significantly lower at $1810 \mathrm{~m}$ and $2200 \mathrm{~m}$ than at $750 \mathrm{~m}, 1320 \mathrm{~m}$ and $1570 \mathrm{~m}$ with the former only accounting for $7 \%-13 \%$ and the latter $17 \%-27 \%$ of total added ${ }^{15} \mathrm{~N}$ (Figure 3). Furthermore, the microorganisms had the similar ${ }^{15} \mathrm{~N}$-glycine uptake ability by the direct route at $1570 \mathrm{~m}$, $1810 \mathrm{~m}$ and $2200 \mathrm{~m}$, which was higher than that of the other treatments.

The microbial immobilized ${ }^{15} \mathrm{~N}$ content was positively correlated with the soil TN and soil organic matter contents but was negatively correlated with the ${ }^{15} \mathrm{~N}^{-\mathrm{NO}_{3}}{ }^{-}$content (Figure 4). The ${ }^{15} \mathrm{~N}_{-} \mathrm{NH}_{4}{ }^{+}$content was positively correlated with the soil $\mathrm{NO}_{3}{ }^{-}$content but negatively correlated with the soil $\mathrm{C} / \mathrm{N}$ ratio, soil organic matter content and soil $\mathrm{TN}$ content (Figure 4). Intact glycine uptake by microorganisms was positively correlated with soil C/N ratio but was negatively correlated with MBN and MBC (Figure 4). 


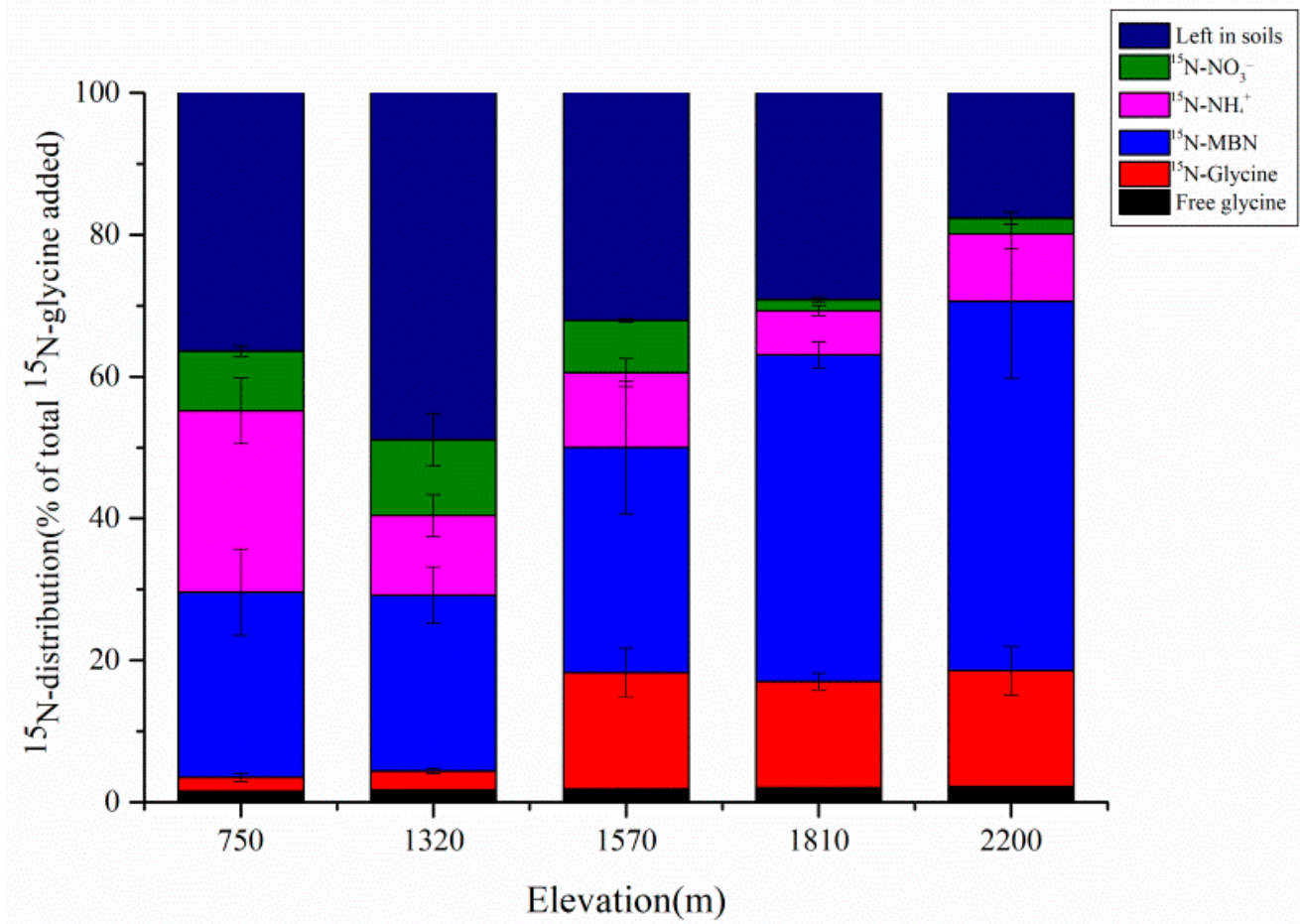

Figure 3. Distributions of ${ }^{15} \mathrm{~N}$-glycine in soils according to elevation gradients. Error bars represent standard deviations of means; $n=6 .{ }^{15} \mathrm{~N}$-Glycine: ${ }^{15} \mathrm{~N}$ was assimilated to soil microbial biomass by direct route; ${ }^{15} \mathrm{~N}-\mathrm{MBN}$ : ${ }^{15} \mathrm{~N}$ was assimilated to soil microbial biomass by MIT route; ${ }^{15} \mathrm{~N}-\mathrm{NH}_{4}{ }^{+}:{ }^{15} \mathrm{~N}$ glycine was mineralized into $\mathrm{NH}_{4}{ }^{+} ;{ }^{15} \mathrm{~N}_{-N_{3}}{ }^{-}:{ }^{15} \mathrm{~N}$ glycine was mineralized into $\mathrm{NO}_{3}{ }^{-}$; free glycine: glycine was in soil solution; left in soils: glycine was left in the soil.

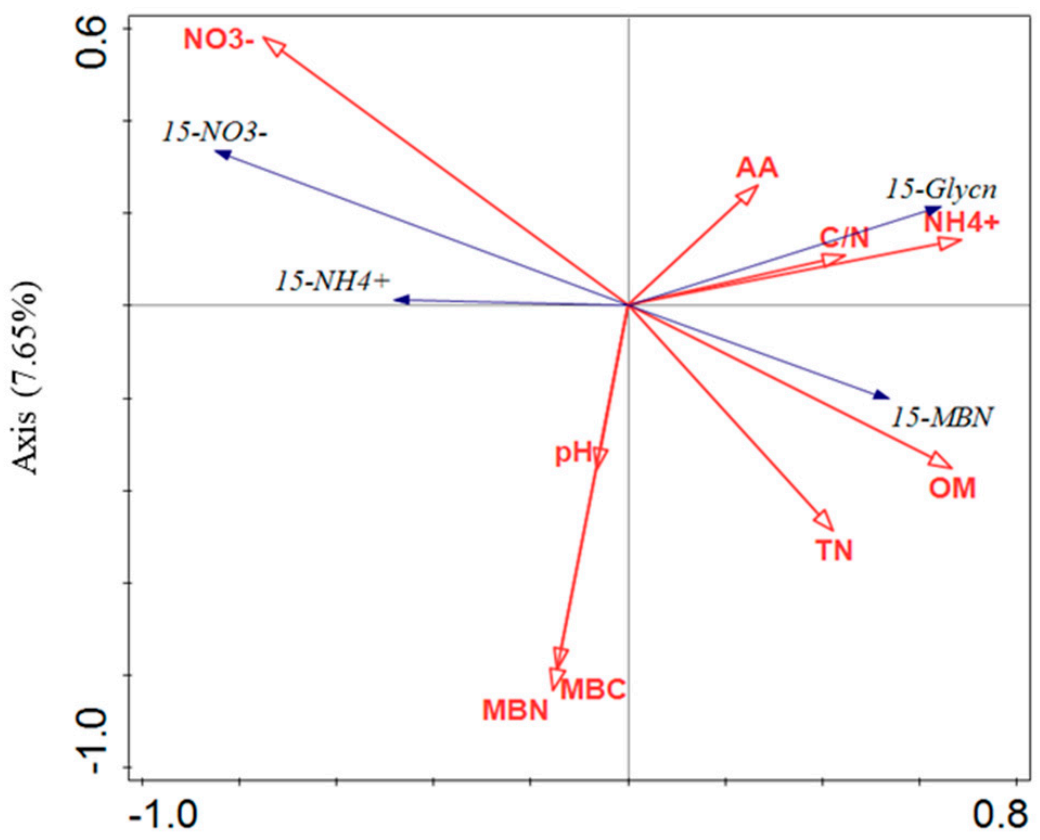

Axis (46.85\%)

Figure 4. Redundancy analysis (RDA) of the relationship of ${ }^{13} \mathrm{C},{ }^{15} \mathrm{~N}$-glycine uptake by soil microorganisms and soil physicochemical properties. ${ }^{15} \mathrm{~N}-\mathrm{MBN}:{ }^{15} \mathrm{~N}$ was assimilated to soil microbial biomass by MIT route; ${ }^{15} \mathrm{~N}-\mathrm{NH}_{4}{ }^{+}:{ }^{15} \mathrm{~N}$ glycine was mineralized into $\mathrm{NH}_{4}{ }^{+} ;{ }^{15} \mathrm{~N}_{-\mathrm{NO}_{3}}{ }^{-}:{ }^{15} \mathrm{~N}$ glycine was mineralized into $\mathrm{NO}_{3}{ }^{-}$; AA: glycine was in soil solution; OM: organic matter. 


\subsection{Analysis of ${ }^{13}$ C-PLFA Incorporation at Each Elevation Treatment}

We used ${ }^{13} \mathrm{C}$-PLFA to study which kinds of microorganisms take an active part in the utilization of ${ }^{13} \mathrm{C}_{1}^{15} \mathrm{~N}$-glycine. In the $1810 \mathrm{~m}$ and $2200 \mathrm{~m}$ groups, the total amount of ${ }^{13} \mathrm{C}$ in PLFAs was significantly higher than that in the other gradient treatments (Figure 5). The ${ }^{13} \mathrm{C}$-labeled PLFA markers varied among the studied soils. Fungi were rarely labeled at any elevation plots (Figure 6). Compared with that at the $750 \mathrm{~m}, 1320 \mathrm{~m}$ and $1570 \mathrm{~m}$ plots, the ratio of i-15:0 which represents G+ bacteria, was much higher at the $2200 \mathrm{~m}$ and $1810 \mathrm{~m}$ plot soils. In addition, the largest ${ }^{13} \mathrm{C}$ enrichment in biomarker PLFAs was found in the G+ bacteria i-16:0. In the $2200 \mathrm{~m}$ plot, the 16:0 (universal) and i16:0 (G+ bacteria) biomarkers were much higher than in the other elevation soils, while $18: 1 \omega 9 \mathrm{c}(\mathrm{G}-$ bacteria) was much lower than in the other elevation soils (Figure 6). The uptake of glycine by G+ bacteria and universal at the $1810 \mathrm{~m}$ and $2200 \mathrm{~m}$ treatment was higher than at other treatments. Furthermore, ${ }^{13} \mathrm{C}$-labeled glycine was rarely tested in the $\mathrm{G}-$ bacteria in the $1810 \mathrm{~m}$ and $2200 \mathrm{~m}$ groups. In the $750 \mathrm{~m}$ and $1570 \mathrm{~m}$ groups, there was no significant difference in ${ }^{13}$ C-PLFA among universal, G+ bacteria and G- bacteria (Figure 7A). In the $2200 \mathrm{~m}$ and $1810 \mathrm{~m}$ groups, ${ }^{13} \mathrm{C}$-labeled $\mathrm{G}+$ bacteria and universal bacteria accounted for $38-43 \%$ and $48-58 \%$ of the total ${ }^{13}$ C-PLFA content, respectively, while G- bacteria and actinomycetes were rarely labeled, indicating that G+ bacteria and universal bacteria played a key role in utilizing glycine addition in the $2200 \mathrm{~m}$ and $1810 \mathrm{~m}$ groups (Figure 7B). The relationship of the amount of ${ }^{13} \mathrm{C}$-PLFA and different soils revealed that ${ }^{13} \mathrm{C}$-labeled $\mathrm{G}+$ bacteria and universal bacteria were positively correlated with MBN. ${ }^{13} \mathrm{C}$-labeled $\mathrm{G}-$-bacteria were positively correlated with the soil $\mathrm{C} / \mathrm{N}$ ratio and soil organic matter content (Figure 8).

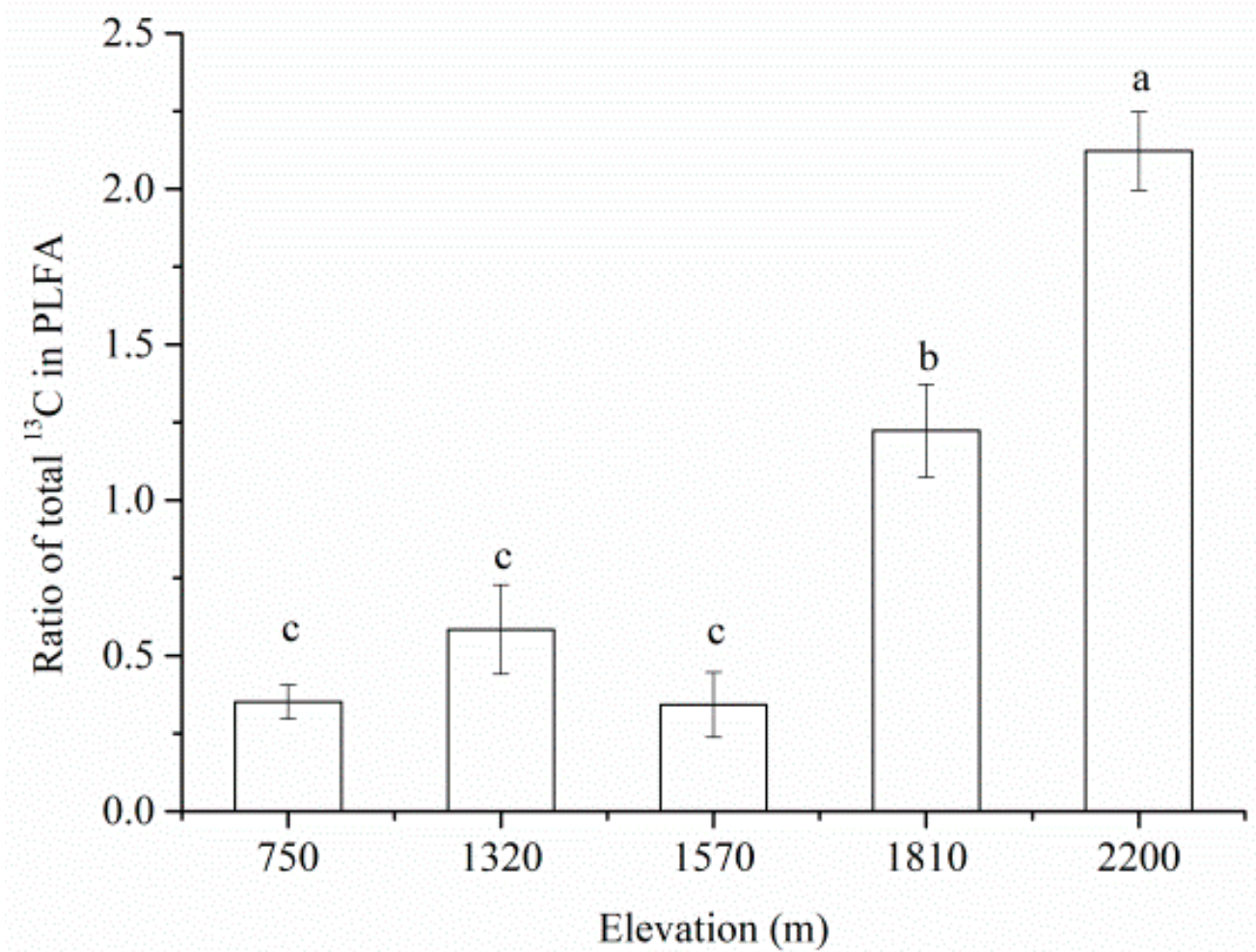

Figure 5. Ratio of ${ }^{13} \mathrm{C}$ labelled in PLFA according to elevation gradients. Error bars represent standard deviations of means; $n=4$. Different superscripted lowercase letters above the bars indicate significant differences among different elevations $(p<0.05)$. 


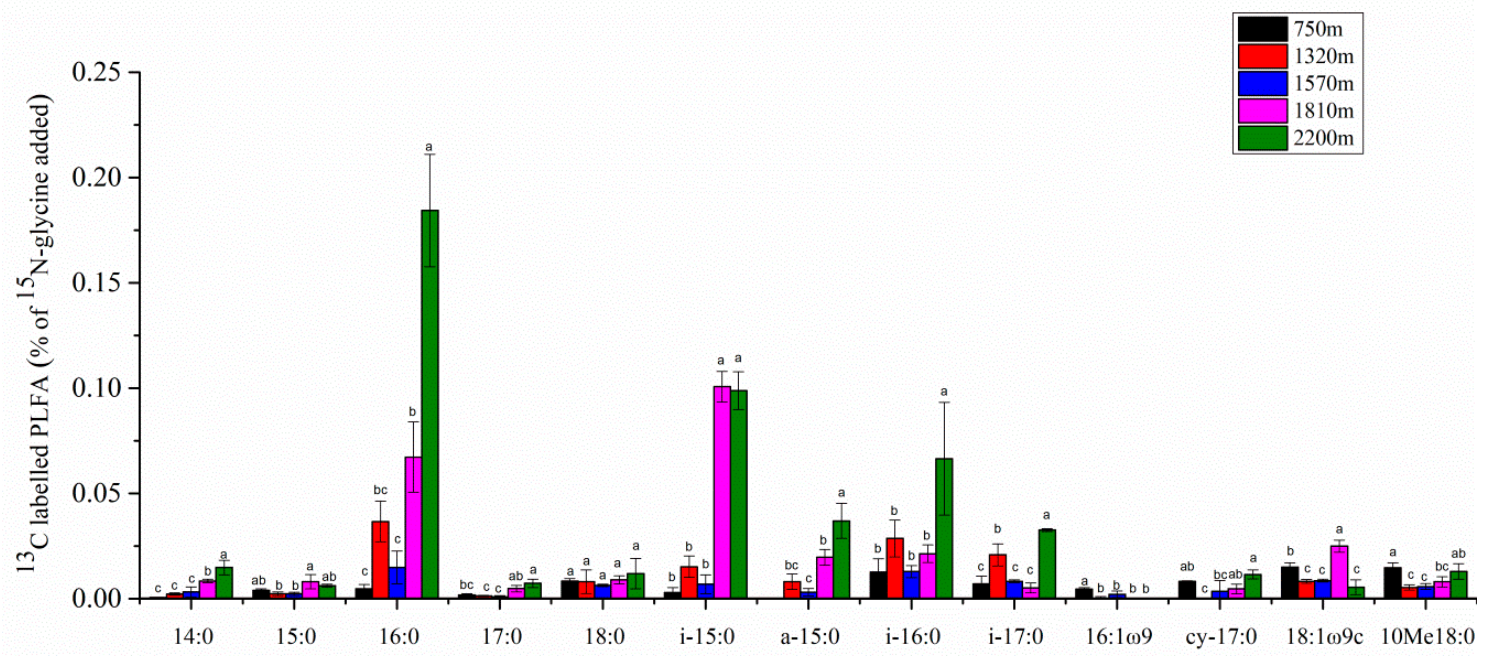

Figure 6. Ratio of ${ }^{13} \mathrm{C}$ labelled in PLFA biomarkers according to elevation gradients. Error bars represent standard deviations of means; $n=4$. Different superscripted lowercase letters above the bars indicate significant differences among different elevations $(p<0.05)$.
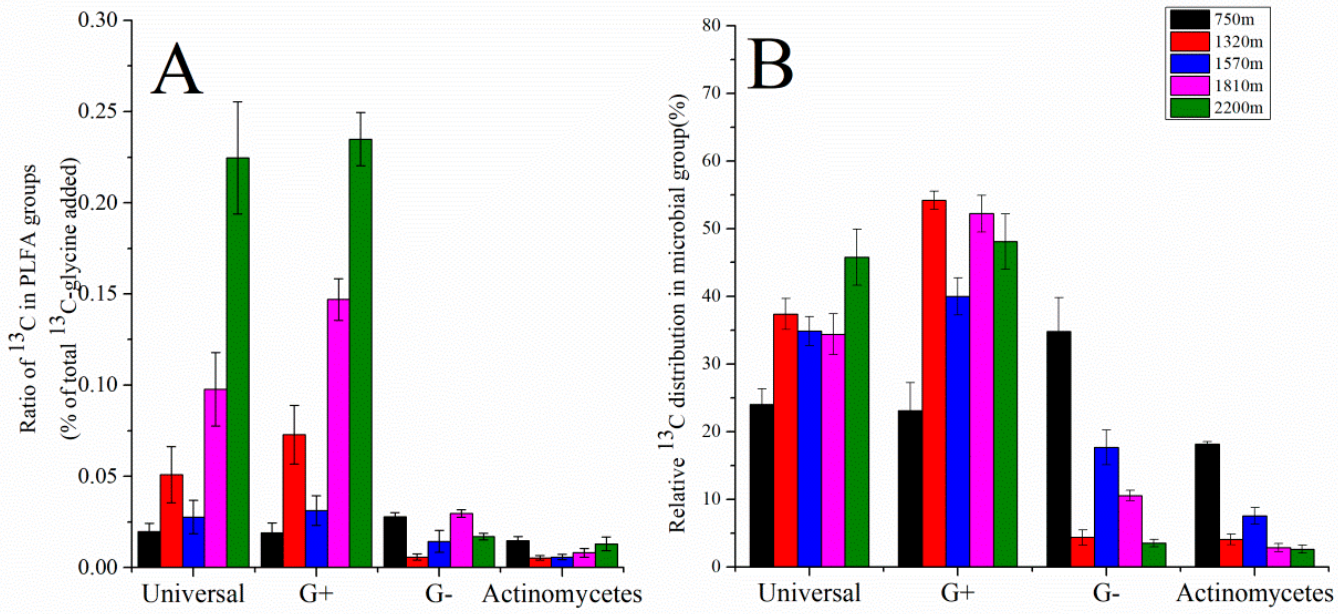

Figure 7. Ratio of ${ }^{13} \mathrm{C}$ labelled in PLFA. Ratio of total ${ }^{13} \mathrm{C}$ added to soil (A). Ratio of total ${ }^{13} \mathrm{C}-\mathrm{PLFA}$ (B). Error bars represent standard deviations of means; $n=4$.

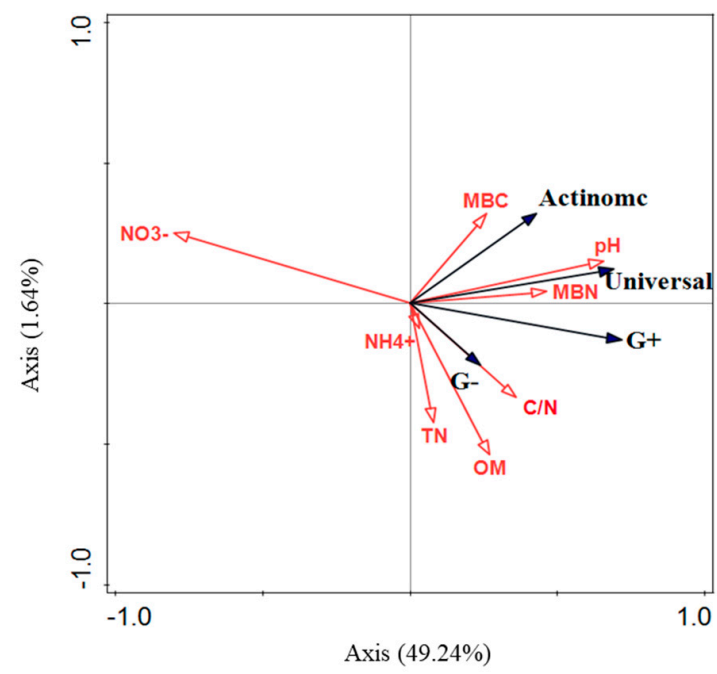

Figure 8. Redundancy analysis (RDA) of the relationship of ${ }^{13}$ C-PLFA in microbial communities and soil physicochemical properties. 


\section{Discussion}

\subsection{Glycine-Addition Effects: The Increased Gross N Mineralization and Microbial Biomass $N$}

We found that glycine increased the rates of gross $\mathrm{N}$ mineralization and microbial $\mathrm{N}$ immobilization, which may have promoted $\mathrm{N}$ transformation (Figures 1 and 2). The quality and quantity of substrate were the key factors for mineral $\mathrm{N}$ production rates [59]. In this study, because of the increases in specific gross $\mathrm{N}$ mineralization rate at all the elevations, the increases in substrate quantity may have a stimulating effect on the gross $\mathrm{N}$ mineralization. In addition, in the upper elevation treatments, the gross rates of $\mathrm{N}$ mineralization were not much influenced by substrate quality since the negative correlations between rates of gross $\mathrm{N}$ mineralization and microbial $\mathrm{C} / \mathrm{N}$ ratios [60].

\subsection{Glycine-Addition Uptake by Soil Microorganisms and Controlling Factors}

Generally, soil microorganisms are considered good competitors for amino acids. Glycine is taken up primarily to fulfill the $\mathrm{C}$ and $\mathrm{N}$ requirements of soil microorganisms, which are able to respond quickly to a transient influx of an easily metabolizable resource [61,62]. Our study revealed that exogenous glycine mainly assimilated by the mineralization-immobilization-turnover (MIT) route in the treatment soils. Apparently, ${ }^{13} \mathrm{C},{ }^{15} \mathrm{~N}$-glycine was mostly immobilized into microbial $\mathrm{N}$ among all the $\mathrm{N}$ forms. The results indicated that the microorganisms favor holding ${ }^{15} \mathrm{NH}_{4}{ }^{+}$into themselvesbecause, coupled with need the source of energy (C) to support their metabolism, the microorganisms also acquired $\mathrm{N}$ to build cellular components, resulting in $\mathrm{N}$ immobilization in biomass. This result was consistent with a study [63] indicating that amino acids could be utilized in the form of microbial $\mathrm{N}$, and deposited $\mathrm{N}$ could exist stably in soil due to this microbial $\mathrm{N}$ immobilization process. Greater orbital immobilization rates of glycine could be expected at relatively high-elevation regions, such as $1810 \mathrm{~m}$ and $2200 \mathrm{~m}$. Similar results in tundra soil were also previously reported [39]. In general, the increase in microbial biomass $\mathrm{N}$ caused by organic $\mathrm{N}$ addition under $\mathrm{N}$ infertility is related to microbial biomass as well as soil $\mathrm{pH}$ and soil organic matter [64].

It has distinct impacts on mineralization and microbial $\mathrm{N}$ immobilization due to soil chemical properties, for example, soil C content, soil $\mathrm{N}$ contents, soil $\mathrm{C} / \mathrm{N}$ ratio, soil organic matter and soil $\mathrm{pH}[47,65,66]$. In this study, we found that the soil $\mathrm{C} / \mathrm{N}$ ratio (not greater than 25) is a critical factor for extraneous ${ }^{13} \mathrm{C},{ }^{15} \mathrm{~N}$-glycine mineralization (Figure 4). Microbes were exposed to $\mathrm{C}$ limitation under relatively low soil $\mathrm{C} / \mathrm{N}$ ratios. The average soil $\mathrm{C} / \mathrm{N}$ ratio was approximately 11.6 in the $750 \mathrm{~m}$ elevation samples (Table 1 ), which was not up to the optimum level of the soil C/N ratio of approximately 14.6 [67]. Therefore, microbes respond quickly to newly supplied C substrates (glycine) for respiration [68], which provides a high-quality $\mathrm{C}$ source and promotes glycine mineralization. However, in relatively high soil $\mathrm{C} / \mathrm{N}$ ratio and poor $\mathrm{N}$ nutrient environments (1810 $\mathrm{m}$ and $2200 \mathrm{~m})$, soil microbes are in situations of $\mathrm{N}$ limitation, and the exogenous glycine may improve this deficiency, consequently decreasing the $\mathrm{N}$ mineralization to lead to $\mathrm{N}$ immobilization and preserve glycine-derived $\mathrm{N}$ in the microbial biomass [12,69]. Moreover, $\mathrm{N}$ immobilization of glycine by microorganisms may be related to the quality and quantity of the soil organic matter (Figure 4). Since rapid stabilization of exogenous organic $\mathrm{N}$ is facilitated by the availability and the content of a readily mineralizable substrate $[33,70]$, we asserted that relatively low C availability at 1800 and 2100 m elevations favors [71] microbial $\mathrm{N}$ immobilization by stimulating heterotrophic microorganisms. These findings also corroborated those of the amino acids added forest soil, where microbial $\mathrm{N}$ immobilization increased with fertility for microorganisms [63].

Previous studies have indicated that directly intact uptake of amino acids was considerable active related to soil microbial $\mathrm{N}$ absorption, especially in extreme environments [40], and this leads to improve available $\mathrm{N}$ supply with relatively low energy [12]. According to the ${ }^{13} \mathrm{C},{ }^{15} \mathrm{~N}$-glycine transformation, we found that $1.9-16.3 \%$ glycine was intactly acquired by the direct uptake route in all the treatments and was significantly higher at upper elevations than at lower elevations. As a result, we concluded that the direct uptake 
route is one of the essential pathways for glycine uptake, which is consistent with the results of Yang et al., especially at upper elevations forest [72]. Furthermore, there was a relative importance between the MIT route and the direct route among the elevation treatments. Offering $\mathrm{C}$ and $\mathrm{N}$ nutrition by a direct uptake route to take part in protein synthesis while also saving a certain amount of energy compared with MIT route [21], the direct route utilizes amino acids to fulfill microorganism growth under the lack of available $\mathrm{C}$ at the upper elevations. Our results are consistent with those of [12,73], who found that amino acids were incorporated by microorganisms by the direct route when soil was in the circumstances of available $\mathrm{C}$ limitation.

The current research showed that the relative dominance of the MIT and direct routes influenced by $\mathrm{N}$ availability, $\mathrm{C}$ source and the availability of $\mathrm{N}$ relative to $\mathrm{C}$ [21]. When inorganic $\mathrm{N}$ was abundant and available $\mathrm{C}$ limited in the $1810 \mathrm{~m}$ and $2200 \mathrm{~m}$ groups (Figure 1) [71], microorganisms met their needs with $\mathrm{NH}_{4}{ }^{+}$and resulted in inhibiting the MIT route and promotion of the direct route of glycine metabolism. A relatively high ratio of direct uptake of glycine was found in the $1570 \mathrm{~m}$ group, which had poor availability of $\mathrm{C}$ [71]. In addition, in the upper elevation treatments, the available $\mathrm{C} / \mathrm{N}$ ratio was relatively high, and $\mathrm{N}$ was limited relative to $\mathrm{C}$. Under this condition, the enzyme systems involved in the uptake of alternative $\mathrm{N}$ sources were likely derepressed [21]. The direct route of exogenous amino acid metabolism should therefore be favored. We found that MBN and $\mathrm{MBC}$ were also factors influencing the direct route, but more research is needed to study these relationships.

\subsection{Microorganisms Actively Utilize Supplied Glycine}

Supplying glycine to trace microbial utilization by enriching PLFA biomarkers with ${ }^{13} \mathrm{C}$ provided an accurate method of the microbial response to amino acid addition on a short-term scale [74]. In our study, ${ }^{13} \mathrm{C}$ from glycine was more rapidly incorporated into PLFAs during the first $6 \mathrm{~h}$, which also explained why an increase in ${ }^{15} \mathrm{~N}$-glycine was found in microbes. We also found that ${ }^{13} \mathrm{C}$-glycine metabolized by fungi was hardly detected in soil at each elevation, and it was mainly incorporated into bacteria, with the detected PLFAs indicative of $\mathrm{G}+$ bacteria and universal bacteria. This observation may be related to the properties of glycine and the characteristics of bacteria. As an easily available C compound, glycine is consumed by many bacteria, but fungi prefer more complex C compounds [39]. Bacteria were also the most sensitive microbial group to the added glycine because bacteria have a much shorter turnover time than fungi and response faster to changes such as elevated $\mathrm{N}$ content in soil conditions [75]. Moreover, vulnerable to limitation of a lack of available $\mathrm{C}$ substrates, bacteria incorporate most of the readily and freshly available substrates even at high soil $\mathrm{C} / \mathrm{N}$ ratio [74]. Similar results were obtained after ${ }^{13} \mathrm{C}^{15} \mathrm{~N}$ glycine addition to temperate heathland [44]. Our data indicate that the favor of exogenous glycine in the bacterial community composition was different with altitude because both $\mathrm{G}+$ and $\mathrm{G}-$ bacteria appeared to be involved in glycine uptake. The labeled PLFAs 16:0 and i-15:0, representing $\mathrm{G}+$ bacteria, were detected with ${ }^{13} \mathrm{C}$ abundances up to $0.07-0.18 \%$ in the $1810 \mathrm{~m}$ and $2200 \mathrm{~m}$ soils, while much less ${ }^{13} \mathrm{C}$ was detected at $750 \mathrm{~m}$. G+ bacteria not only utilize more ${ }^{13} \mathrm{C}$-glycine in high-elevation soil than in low-elevation soil but are also more abundant than $\mathrm{G}-$ bacteria [44]. Unfortunately, little data are available from the literature for comparison under similar conditions. According to our study, ${ }^{13} \mathrm{C}$ enrichment suggests that $\mathrm{G}+$ bacteria seem to express opportunistic substrate use, representing organisms that quickly acquire new substrates and, on a short time scale, incorporated most of the newly added glycine substrate under the prevailing conditions at high altitudes (low temperatures and low nutrient contents); this result may be attributed to the ability of G+ bacteria to grow relatively well when subjected to freeze-thaw cycles [76]. This result seems to conform to the hypothesis of the $\mathrm{r}-\mathrm{K}$ scheme, which assumes that $\mathrm{G}+$ bacteria, as a $\mathrm{K}$ strategist, tend to be relatively successful at taking advantage of resources in resource-limited areas and that, as an r strategist, G- bacteria grow under substrate-rich conditions [77]. Therefore, smallmolecule-organic $\mathrm{N}$ may facilitate the routing of $\mathrm{C}$ by bacteria, which may source amino 
acids, as already observed in the experiment. In conclusion, microbial immobilization of $\mathrm{N}$ mainly had an enhancing effect on usage of glycine by the $\mathrm{G}+$ bacterial in a short time by compensating for low soil quality. The soil $\mathrm{C} / \mathrm{N}$ ratio was positively correlated with $\mathrm{G}-$ bacteria PLFA abundance, indicating that the soil $\mathrm{C} / \mathrm{N}$ ratio likely played an important role in the utilization of amino acids.

\section{Conclusions}

Soil microorganisms had a strong influence on gross $\mathrm{N}$ mineralization and developed different pathways to utilize exogenous glycine in the 750-2200 m altitude range along the Changbai Mountain over a short time. The soil $\mathrm{C} / \mathrm{N}$ ratio was one of the main factors related to the MIT and direct routes. G+ bacteria primarily drove the assimilation of exogenous glycine under this experimental condition. Future research should focus on the effects of environmental factors and soil properties on the competitive uptake of organic nitrogen by plants and soil microorganisms to forecast the evolution of $\mathrm{N}$ cycle in the Changbai Mountain forest system.

Supplementary Materials: The following supporting information can be downloaded at: https: / www. mdpi.com/article/10.3390/f13020307/s1, Figure S1: Net N mineralization according to elevation gradients (means \pm S.D., $n=6$ ); Figure S2: The vegetation of the studied sites from $750 \mathrm{~m}$ to $2200 \mathrm{~m}$ along the altitude Changbai Mountain; Figure S3: The set-up of 15NH4+ pool experiment; Table S1: Pearson correlation coefficients ( $n=6$ plots) among rates of gross $\mathrm{N}$ mineralization, soil water content, $\mathrm{pH}, \mathrm{C}(\%), \mathrm{N}(\%)$ and $\mathrm{C} / \mathrm{N}$ all measured analyzed for all treatment plots. Z.W. (Zhijie Wu) Z.W. (Zhanbo Wei)

Author Contributions: Conceptualization, Y.X., Z.W. (Zhijie Wu) and L.Z.; formal analysis, Y.X.; funding acquisition, L.Z.; investigation, Z.W. (Zhijie Wu) and L.Z.; methodology, Y.X.; resources, D.L., L.Y., P.G., Z.W. (Zhanbo Wei), Y.S., L.C., K.W. and F.X.; supervision, Y.X., Z.W. (Zhijie Wu) and L.Z.; writing-original draft, Y.X.; writing—review and editing, Y.X., Z.W. (Zhijie Wu), W.B. and L.Z. All authors have read and agreed to the published version of the manuscript.

Funding: This research was funded by the Strategic Priority Research Program of the Chinese Academy of Sciences (XDA28090200), the National Scientific Foundation Project of China (31971531) and Liaoning "Take the Lead" Project of 2021: Arable Land Productivity improvement strategies development and promotion (LNJBGS HT202102).

Data Availability Statement: All relevant data is contained within the article.

Acknowledgments: We thank Changbai Mountain Forest Ecosystem National Field Observation and Research Station for supplying an experimental platform, and thank Ji Ye and Guanhua Dai for their assistance with the sample collection, and Yalan Cui for her assistance with experiment.

Conflicts of Interest: The authors declare no conflict of interest.

\section{References}

1. LeBauer, D.S.; Treseder, K.K. Nitrogen limitation of net primary productivity in terrestrial ecosystems is globally distributed. Ecology 2008, 89, 371-379. [CrossRef] [PubMed]

2. Lu, M.; Yang, Y.H.; Luo, Y.Q.; Fang, C.M.; Zhou, X.H.; Chen, J.K.; Yang, X.; Li, B. Responses of ecosystem nitrogen cycle to nitrogen addition: A meta-analysis. New Phytol. 2011, 189, 1040-1050. [CrossRef] [PubMed]

3. Miller, A.E.; Bowman, W.D. Variation in nitrogen-15 natural abundance and nitrogen uptake traits among co-occurring alpine species: Do species partition by nitrogen form? Oecologia 2002, 130, 609-616. [CrossRef] [PubMed]

4. Hill, P.W.; Farrell, M.; Roberts, P.; Farrar, J.; Grant, H.; Newsham, K.K.; Hopkins, D.W.; Bardgett, R.D.; Jones, D.L. Soil- and enantiomer-specific metabolism of amino acids and their peptides by Antarctic soil microorganisms. Soil Biol. Biochem. 2011, 43, 2410-2416. [CrossRef]

5. Fischer, H.; Ingwersen, J.; Kuzyakov, Y. Microbial uptake of low-molecular-weight organic substances out-competes sorption in soil. Eur. J. Soil Sci. 2010, 61, 504-513. [CrossRef]

6. Jones, D.L.; Hodge, A. Biodegradation kinetics and sorption reactions of three diferently charged amino acids in soil and their efects on plant organic nitrogen availability. Soil Biol. Biochem. 1999, 31, 1331-1342. [CrossRef]

7. Roberts, P.; Newsham, K.K.; Bardgett, R.D.; Farrar, J.F.; Jones, D.L. Vegetation cover regulates the quantity, quality and temporal dynamics of dissolved organic carbon and nitrogen in Antarctic soils. Polar Biol. 2009, 32, 999-1008. [CrossRef] 
8. Ma, Q.X.; Wu, L.H.; Wang, J.; Ma, J.Z.; Zheng, N.G.; Hill, P.W.; Chadwick, D.R.; Jones, D.L. Fertilizer regime changes the competitive uptake of organic nitrogen by wheat and soil microorganisms: An in-situ uptake test using ${ }^{13} \mathrm{C},{ }^{15} \mathrm{~N}$ labelling, and ${ }^{13}$ C-PLFA analysis. Soil Biol. Biochem. 2018, 125, 319-327. [CrossRef]

9. Philben, M.; Ziegler, S.E.; Edwards, K.A.; Kahler, R.; Benner, R. Soil organic nitrogen cycling increases with temperature and precipitation along a boreal forest latitudinal transect. Biogeochemistry 2016, 127, 397-410. [CrossRef]

10. Kaiser, K.; Canedo-Oropeza, M.; Mcmahon, R.; Amon, R.M.W. Origins and transformations of dissolved organic matter in large Arctic rivers. Sci. Rep. 2017, 7, 13064. [CrossRef]

11. Nordin, A.; Schmidt, I.K.; Shaver, G.R. Nitrogen uptake by arctic soil microbes and plants in relation to soil nitrogen supply. Ecology 2004, 85, 955-962. [CrossRef]

12. Geisseler, D.; Horwath, W.R.; Doane, T.A. Significance of organic nitrogen uptake from plant residues by soil microorganisms as affected by carbon and nitrogen availability. Soil Biol. Biochem. 2009, 41, 1281-1288. [CrossRef]

13. Liu, M.; Li, C.C.; Xu, X.L.; Wanek, W.; Jiang, N.; Wang, H.M.; Yang, X.D. Organic and inorganic nitrogen uptake by 21 dominant tree species in temperate and tropical forests. Tree Physiol. 2017, 37, 1515-1526. [CrossRef] [PubMed]

14. Geisseler, D.; Joergensen, R.G.; Ludwig, B. Temporal effect of straw addition on amino acid utilization by soil microorganisms. Eur. J. Soil Biol. 2012, 53, 107-113. [CrossRef]

15. Nordin, A.; Hogberg, P.; Nasholm, T. Soil nitrogen form and plant nitrogen uptake along a boreal forest productivity gradient. Oecologia 2001, 129, 125-132. [CrossRef]

16. Apostel, C.; Dippold, M.A.; Glaser, B.; Kuzyakov, Y. Biochemical pathways of amino acids in soil: Assessment by position-specific labeling and ${ }^{13}$ C-PLFA analysis. Soil Biol. Biochem. 2013, 67, 31-40. [CrossRef]

17. Glanville, H.C.; Hill, P.W.; Schnepf, A.; Oburger, E.; Jones, D.L. Combined use of empirical data and mathematical modelling to better estimate the microbial turnover of isotopically labelled carbon substrates in soil. Soil Biol. Biochem. 2016, 94, 154-168. [CrossRef]

18. Jansson, S.L. Tracer studies on nitrogen transformations in soil with special attention to mineralization-immobilization relationships. Ann. Roy. Coll. Surg. 1958, 24, 101-306.

19. Barraclough, D. The direct or MIT route for nitrogen immobilization: A ${ }^{15} \mathrm{~N}$ mirror image study with leucine and glycine. Soil Biol. Biochem. 1997, 29, 101-108. [CrossRef]

20. Myrold, D.D.; Bottomley, P.J. Nitrogen mineralization and immobilization. In Nitrogen in Agricultural Systems; Schepers, J.S., Raun, W.R., Eds.; American Society of Agronomy, Crop Science Society of America, Soil Science Society of America: Madison, WI, USA, 2008; Volume 49, pp. 157-172.

21. Geisseler, D.; Horwath, W.R.; Joergensen, R.G.; Ludwig, B. Pathways of nitrogen utilization by soil microorganisms: A review. Soil Biol. Biochem. 2010, 42, 2058-2067. [CrossRef]

22. Baldos, A.P.; Corre, M.D.; Veldkamp, E. Response of N cycling to nutrient inputs in forest soils across a 1000-3000 m elevation gradient in the Ecuadorian Andes. Ecology 2015, 96, 749-761. [CrossRef]

23. Booth, M.S.; Stark, J.M.; Rastetter, E. Controls on nitrogen cycling in terrestrial ecosystems: A synthetic analysis of literature data. Ecol. Monogr. 2005, 75, 139-157. [CrossRef]

24. Urakawa, R.; Ohte, N.; Shibata, H.; Isobe, K.; Tateno, R.; Oda, T.; Hishi, T.; Fukushima, K.; Inagaki, Y.; Hirai, K.; et al. Factors contributing to soil nitrogen mineralization and nitrification rates of forest soils in the Japanese archipelago. For. Ecol. Manag. 2016, 361, 382-396. [CrossRef]

25. Colman, B.P.; Schimel, J.P. Drivers of microbial respiration and net N mineralization at the continental scale. Soil Biol. Biochem. 2013, 60, 65-76. [CrossRef]

26. Zhu, T.B.; Meng, T.Z.; Zhang, J.B.; Yin, Y.F.; Cai, Z.C.; Yang, W.Y.; Zhong, W.H. Nitrogen mineralization, immobilization turnover, heterotrophic nitrification, and microbial groups in acid forest soils of subtropical China. Biol. Fertil. Soils 2013, 49, 323-331. [CrossRef]

27. Tahovská, K.; Kaňa, J.; Bárta, J.; Oulehle, F.; Richter, A.; Šantrůčková, H. Microbial N immobilization is of great importance in acidified mountain spruce forest soils. Soil Biol. Biochem. 2013, 59, 58-71. [CrossRef]

28. Fujii, K.; Yamada, T.; Hayakawa, C.; Nakanishi, A.; Funakawa, S. Decoupling of protein depolymerization and ammonification in nitrogen mineralization of acidic forest soils. Appl. Soil Ecol. 2020, 153, 103572. [CrossRef]

29. Cao, Y.S.; He, Z.L.; Zhu, T.B.; Zhao, F.L. Organic-C quality as a key driver of microbial nitrogen immobilization in soil: A meta-analysis. Geoderma 2021, 383, 114784. [CrossRef]

30. Bengtsson, G.; Bengtson, P.; Månsson, K.F. Gross nitrogen mineralization-, immobilization-, and nitrification rates as a function of soil C/N ratio and microbial activity. Soil Biol. Biochem. 2003, 35, 143-154. [CrossRef]

31. Månsson, K.; Bengtson, P.; Falkengren-Grerup, U.; Bengtsson, G. Plant-microbial competition for nitrogen uncoupled from soil C:N ratios. Oikos 2009, 118, 1908-1916. [CrossRef]

32. Hooker, T.D.; Stark, J.M. Carbon flow from plant detritus and soil organic matter to microbes: Linking carbon and nitrogen cycling in semiarid soils. Soil Sci. Soc. Am. J. 2012, 76, 903-914. [CrossRef]

33. Fritz, C.; Wichern, F. In the land of plenty: Catch crops trigger nitrogen uptake by soil microorganisms. Plant Soil 2018, 423, 549-562. [CrossRef]

34. Warren, C.R. Uptake of inorganic and amino acid nitrogen from soil by Eucalyptus regnans and Eucalyptus pauciflora seedlings. Tree Physiol. 2009, 29, 401-409. [CrossRef] 
35. Cookson, W.R.; Osman, M.; Marschner, P.; Clark, I.M.; Murphy, D.V.; Stockdale, E.A.; Watson, C.A. Controls on soil nitrogen cycling and microbial community composition across land use and incubation temperature. Soil Biol. Biochem. 2007, 39, 744-756. [CrossRef]

36. Frostegard, A.; Tunlid, A.; Baath, E. Use and misuse of PLFA measurements in soils. Soil Biol. Biochem. 2011, 43, 1621-1625. [CrossRef]

37. Dungait, J.A.J.; Kemmitt, S.J.; Michallon, L.; Guo, S.L.; Wen, Q.; Brookes, P.C.; Evershed, R.P. The variable response of soil microorganisms to trace concentrations of low molecular weight organic substrates of increasing complexity. Soil Biol. Biochem. 2013, 64, 57-64. [CrossRef]

38. Bardgett, R.D.; Steeter, T.C.; Bol, R. Soil microbes compete effectively with plants for organic-nitrogen inputs to temperate grasslands. Ecology 2003, 84, 1277-1287. [CrossRef]

39. Rinnan, R.; Baath, E. Differential utilization of carbon substrates by bacteria and fungi in tundra soil. Appl. Environ. Microbiol. 2009, 75, 3611-3620. [CrossRef]

40. Gunina, A.; Dippold, M.A.; Glaser, B.; Kuzyakov, Y. Fate of low molecular weight organic substances in an arable soil: From microbial uptake to utilisation and stabilisation. Soil Biol. Biochem. 2014, 77, 304-313. [CrossRef]

41. Broughton, R.C.I.; Newsham, K.K.; Hill, P.W.; Stott, A.; Jones, D.L. Differential acquisition of amino acid and peptide enantiomers within the soil microbial community and its implications for carbon and nitrogen cycling in soil. Soil Biol. Biochem. 2015, 88, 83-89. [CrossRef]

42. Abbruzzese, V.; Semple, K.T.; Haygarth, P.M.; Aller, M.F.; Russell, E.; Surridge, B.W.J. Effects of substrate quality on carbon partitioning and microbial community composition in soil from an agricultural grassland. Appl. Soil Ecol. 2021, 161, 103881. [CrossRef]

43. Butler, J.L.; Williams, M.A.; Bottomley, P.J.; Myrold, D.D. Microbial community dynamics associated with rhizosphere carbon flow. Appl. Environ. Microbiol. 2003, 69, 6793-6800. [CrossRef] [PubMed]

44. Andresen, L.C.; Dungait, J.A.J.; Bol, R.; Selsted, M.B.; Ambus, P.; Michelsen, A. Bacteria and fungi respond differently to

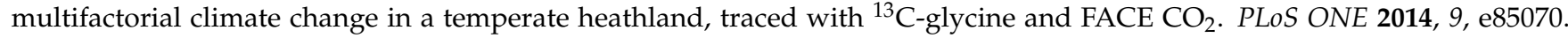
[CrossRef]

45. Bray, S.R.; Kitajima, K.; Mack, M.C. Temporal dynamics of microbial communities on decomposing leaf litter of 10 plant species in relation to decomposition rate. Soil Biol. Biochem. 2012, 49, 30-37. [CrossRef]

46. Zhang, M.; Zhang, X.K.; Liang, W.J.; Jiang, Y.; Dai, G.H.; Han, S.J. Distribution of soil organic carbon fractions along the altitudinal gradient in the northern slope of Changbai Mountain. Pedoshphere 2011, 21, 615-620. [CrossRef]

47. Lu, M.Z.; Cheng, S.L.; Fang, H.J.; Xu, M.; Yang, Y.; Li, Y.N.; Zhang, J.B.; Müller, C. Organic nitrogen addition causes decoupling of microbial nitrogen cycles by stimulating gross nitrogen transformation in a temperate forest soil. Geoderma 2021, $385,114886$. [CrossRef]

48. Zhang, N.; Yu, G.R.; Yu, Z.L.; Zhao, S.D. Analysis on factors affecting net primary productivity distribution in Changbai Mountain based on process model for landscape scale. J. Appl. Ecol. 2003, 14, 659-664.

49. Tong, F.C.; Xiao, Y.H.; Wang, Q.L. Soil nematode community structure on the northern slope of Changbai Moutain, Northeast China. J. Forest Res. 2010, 21, 93-98. [CrossRef]

50. Zhang, B.; Liang, C.; He, H.; Zhang, X. Variations in soil microbial communities and residues along an altitude gradient on the northern slope of Changbai Mountain, China. PLoS ONE 2013, 8, e66184. [CrossRef]

51. Brookes, P.C.; Landman, A.; Pruden, G.; Jenkinson, D.S. Chloroform fumigation and the release of soil nitrogen: A rapid direct extraction method to measure microbial biomass nitrogen in soil. Soil Biol. Biochem. 1985, 17, 837-842. [CrossRef]

52. Sebilo, M.; Mayer, B.; Grably, M.; Billiou, D.; Mariotti, A. The use of the 'ammonium diffusion' method for $\delta^{15} \mathrm{~N}-\mathrm{NH}_{4}{ }^{+}$and $\delta^{15} \mathrm{~N}_{-N_{3}}{ }^{-}$measurements: Comparison with other techniques. Environ. Chem. 2004, 1, 99-103. [CrossRef]

53. Geisseler, D.; Horwath, W.R. Investigating amino acid utilization by soil microorganisms using compound specific stable isotope analysis. Soil Biol. Biochem. 2014, 74, 100-105. [CrossRef]

54. Smart, K.F.; Aggio, R.B.; Van Houtte, J.R.; Villas-Bôas, S.G. Analytical platform for metabolome analysis of microbial cells using methyl chloroformate derivatization followed by gas chromatography-mass spectrometry. Nat. Protoc. 2010, 5, 1709-1729. [CrossRef] [PubMed]

55. Cabrera, M.L.; Beare, M.H. Alkaline persulfate oxidation for determining total nitrogen in microbial biomass extracts. Soil Sci. Soc. Am. J. 1993, 57, 1007-1012. [CrossRef]

56. Thornton, B.; Zhang, Z.; Mayes, R.W.; Högberg, M.N.; Midwood, A.J. Can gas chromatography combustion isotope ratio mass spectrometry be used to quantify organic compound abundance? Rapid Commun. Mass Spectrom. 2011, 25, 2433-2438. [CrossRef]

57. Bååth, E. The use of neutral lipid fatty acids to indicate the physiological conditions of soil fungi. Microb. Ecol. 2003, 45, 373-383. [CrossRef]

58. Frostegård, Å.; Bååth, E. The use of phospholipid fatty acid analysis to estimate bacterial and fungal biomass in soil. Biol. Fertil. Soils 1996, 22, 59-65. [CrossRef]

59. Mazzarino, M.J.; Bertiller, M.B.; Sain, C.; Satti, P.; Coronato, F. Soil nitrogen dynamics in northeastern Patagonia steppe under different precipitation regimes. Plant Soil 1998, 202, 125-131. [CrossRef]

60. Hart, S.C.; Nason, G.E.; Myrold, D.D.; Perry, D.A. Dynamics of gross nitrogen transformations in an old-growth forest: The carbon connection. Ecology 1994, 75, 880-891. [CrossRef] 
61. Owen, A.G.; Jones, D.L. Competition for amino acids between wheat roots and rhizosphere microorganisms and the role of amino acids in plant N acquisition. Soil Biol. Biochem. 2001, 33, 651-657. [CrossRef]

62. Jones, D.L.; Shannon, D.; Murphy, D.V.; Farrar, J. Role of dissolved organic nitrogen (DON) in soil N cycling in grassland soils. Soil Biol. Biochem. 2004, 36, 749-756. [CrossRef]

63. Rothstein, D.E. Effects of amino-acid chemistry and soil properties on the behavior of free amino acids in acidic forest soils. Soil Biol. Biochem. 2010, 42, 1743-1750. [CrossRef]

64. Treseder, K.K. Nitrogen additions and microbial biomass: A meta-analysis of ecosystem studies. Ecol. Lett. 2008, 11, 1111-1120. [CrossRef] [PubMed]

65. Schimel, J.P.; Bennett, J. Nitrogen mineralization: Challenges of a changing paradigm. Ecology 2004, 85, 591-602. [CrossRef]

66. Dippold, M.A.; Kuzyakov, Y. Biogeochemical transformations of amino acids in soil assessed by position-specific labeling. Plant Soil 2013, 373, 385-401. [CrossRef]

67. Cheng, Y.; Wang, J.; Wang, J.Y.; Wang, S.Q.; Chang, S.X.; Cai, Z.C.; Zhang, J.B.; Niu, S.L.; Hu, S.J. Nitrogen deposition differentially affects soil gross nitrogen transformations in organic and mineral horizons. Earth Sci. Rev. 2020, 201, 103033. [CrossRef]

68. Jones, D.L.; Kemmitt, S.J.; Wright, D.; Cuttle, S.P.; Bol, R.; Edwards, A.C. Rapid intrinsic rates of amino acid biodegradation in soils are unaffected by agricultural management strategy. Soil Biol. Biochem. 2005, 37, 1267-1275. [CrossRef]

69. Averill, C.; Waring, B. Nitrogen limitation of decomposition and decay: How can it occur? Glob. Change Biol. 2018, 24, 1417-1427. [CrossRef]

70. Barrett, J.E.; Burke, I.C. Potential nitrogen immobilization in grassland soils across a soil organic matter gradient. Soil Biol. Biochem. 2000, 32, 1707-1716. [CrossRef]

71. Cong, G.; Zhang, Z.D.; Zhang, J.J.; Xu, L.; He, N.P. Research on Characteristics of Soil Organic Carbon in Different Forest Types in Changbai Mountain. J. Soil Water Conserv. 2019, 33, 179-184.

72. Yang, L.J.; Zhang, L.L.; Geisseler, D.; Wu, Z.J.; Gong, P.; Xue, Y.; Yu, C.X.; Juan, Y.H.; Horwath, W.R. Available C and N affect the utilization of glycine by soil microorganisms. Geoderma 2016, 283, 32-38. [CrossRef]

73. Farrell, M.; Macdonald, L.M.; Hill, P.W.; Wanniarachchi, S.D.; Farrar, J.; Bardgett, R.D.; Jones, D.L. Amino acid dynamics across a grassland altitudinal gradient. Soil Biol. Biochem. 2014, 76, 179-182. [CrossRef]

74. Kuzyakov, Y.; Gavrichkova, O. Time lag between photosynthesis and carbon dioxide efflux from soil: A review of mechanisms and controls. Glob. Chang. Biol. 2010, 16, 3386-3406. [CrossRef]

75. Denef, K.; Roobroeck, D.; Wadu, M.C.M.; Lootens, P.; Boeckx, P. Microbial community composition and rhizodeposit-carbon assimilation in differently managed temperate grassland soils. Soil Biol. Biochem. 2009, 41, 144-153. [CrossRef]

76. Mitchell, R.J.; Hester, A.J.; Campbell, C.D.; Chapman, S.J.; Cameron, C.M.; Hewison, R.L.; Potts, J.M. Explaining the variation in the soil microbial community: Do vegetation composition and soil chemistry explain the same or different parts of the microbial variation? Plant Soil 2012, 351, 355-362. [CrossRef]

77. Margesin, R.; Jud, M.; Tscherko, D.; Schinner, F. Microbial communities and activities in alpine and subalpine soils. FEMS Microbiol. Ecol. 2009, 67, 208-221. [CrossRef] 